\title{
THE ROLE OF SOCIO-ECONOMIC ASPECTS OF WOMEN ON INFANT MORTALITY: A PANEL DATA ANALYSES FOR OECD COUNTRIES
}

Murat KÜRKCÜ1
Orhan KANDEMIR²
Received Date (Başvuru Tarihi): 18/10/2017

Accepted Date (Kabul Tarihi): 10/12/2017

Published Date (Yayın Tarihi): 20/12/2017

\begin{abstract}
Social and economic development of a nation is often reflected by the existing infant and child mortality rates. In this context, one of the millennium development goals is to reduce infant and child mortalities globally. In particular, women's socio-economic positions are important variables in explaining infant/child mortality. The correlation between infant/child mortalities and socio-economic positions of women is very strong. This study uses a panel data analysis to measure the effect of labourforce participation rate of women on infant/child mortalities. The present article analyzes how women's socio-economic situations affect infant/child mortality in OECD countries for the era 2000-2014. Our results are statistically significant and also suitable for theoretical expectations. According to our conclusions mortality rates may decline as a result of the increase in labourforce participation rates of women. In this context, there is a negative relationship between the labor force participation rate of women and gender inequality. So, as gender inequality decreases, infant/child mortality rates also decrease.
\end{abstract}

Keywords: Development, Gender Equality, Infant Mortality

JEL Code: 010,114

\section{KADINLARIN SOSYO-EKONOMIK DURUMLARININ BEBEK ÖLÜMLERİ ÜZERINDEKI ROLÜ: OECD ÜLKELERI ICÇIN PANEL VERİ ANALIZI}

ÖZ

Bir ülkenin sosyal ve ekonomik gelişme düzeyi genellikle bebek ve çocuk ölüm oranları tarafindan yansıtılmaktadır. Bu bağlamda, milenyum kalkınma amaçlarından birisi de bebek ve çocuk ölüm oranlarını küresel düzeyde azaltmaktır. Özellikle, kadınların sosyo-ekonomik durumları bebek/çocuk ölümlerini

\footnotetext{
${ }^{1}$ Dr., Maliye Bakanlığı Muhasebat Genel Müdürlüğü, murat_kurkcu@ hotmail.com

2 Yrd. Doç. Dr., Kastamonu Üniversitesi, İ.İ.B.F., İktisat Bölümü, okandemir@ kastamonu.edu.tr
}

http://orcid.org/0000-0003-0169-4203 http://orcid.org/0000-0002-9274-3420 
açıklamakta kullanılan önemli değişkenlerdendir. Bebek/çocukölümleri ve kadınların sosyo ekonomikdurumlar arasındaki ilişki çok güçlüdür. Bu araştırma da kadınların işgücüne katılım oranının bebek/çocuk ölümleri üzerindeki etkisini ölçmek için panel veri analizi kullanılmıştır. Makale ile kadınların sosyo-ekonomik durumlarının 2000-2014 döneminde OECD ülkelerinde bebek/çocuk ölümlerini nasıl etkilediği analiz edilmiştir. Elde edilen sonuçlar istatistiksel olarak anlamlı ve teorik beklentilere uygundur. Analiz sonuçlarına göre, beb ek ve çocuk ölüm oranları kadınların işgücüne katılım oranlarındaki artış sayesinde düşebilir. Bu băglamda kadınların işgücüne katılım oranı ve cinsiyet eşitsizliği arasında negatifbir ilişki vardır. Dolayısıyla, cinsiyet eşitsizliği azaldıkça bebek/çocukölümoranları da azalmaktadır.

Anahtar Kelimeler: Kalkınma, Cinsiyet Eşitliği, Bebek Ölümü

JEL Kodları: O10, 114

\section{INTRODUCTION}

One of the Millennium Development Goals is also to minimize in the ratio of two thirds under-five year mortality rate between the years 1990 and 2015. Worldwide, while the mortality rate for children under age five is 90 deaths per 1000 live births in 1990, this rate dropped to 48 in 2012. Therefore it was provided almost a fifty percent decline but this decline drop behind the target of two third (UNDP, 2014:24).

According to Houweling and Kunst (2010), there is a strong correlation between child mortalities and socio-economic positions of their parents in low and middle income countries, child mortalities are higher among especially low socio-economic groups.

Thus, it has been defined as a target both strengthening of women's position and reducing of infant and child mortalities in millenium development goals. While one of the indicators of the goals of strenghtehing position of women and providing gender equality is the situation of women's participate in education in all levels of education (primary, secondary and high education), one other is tackled as the ratio of women in wage employment in non-agricultural sector and the ratio of women parliamentarians in parliament (SPO, 2010:66).

Infant mortality rate (IMR), which is known as an important indicator of community health, is extremely susceptive to structural factors as socio-economic development.

For reducing of infant and child mortality it has particularly been drawn attention to the importance of improving the educational level of women beside other measures. Because it is emphasized that the increase in the mother's level of education and family welfare level has a significant impact on the reduction of infant and under-five child mortality rate (SPO, 2010:33-35).

In this context, the main purpose of the study is to determine -for reduction of infant mortality also mentioned in the millennium development goals- whether the maternal socioeconomic status is a decisive factor. 
The lessening of gender inequality as regards the rates of employment and participation in the labor force will perform important contributions in the economy (Şimşek, 2014:183).

Usually, it can be said that elements like the education level and employment as the determinants of socio-economic status of women in the studies on the subject are considered (Dallolio et al., 2012; Mustafa and Odimegwu, 2008). Thus, the impacts of labor force participation rates, one of the factors determining women's socio-economic status, on infant mortality have been evaluated by using the data among 2000-2014 years in OECD countries in this study. The (infant/neonata//under five) mortality rate (hereafter MR) data ${ }^{3}$ and the women's labour force participation rate (hereafter LFPR) data used in the analysis are respectively taken from WHO (World Health Organization) and OECD.Stat.

The next secitions of this paper is planned as follows. The literature review is given in section 2. Section 3 introduces the methodology and data. The empirical analysis has been described in section 4. And the conclusion is in the last section.

\section{LITERATURE REVIEW}

As expressed in the millennium development goals for reducing infant and child mortality through education and employment it is necessary to strengthen the social and economic aspects of women (Mustafa and Odimegwu, 2008).

In the literature, generally the increase in the educational level of mothers seems to be an important factor in decreasing the infant and child mortality (Cleland and Ginneken, 1988; Caldwell and McDonald, 1982; Tulasidhar, 1993; Song and Burgard, 2011; Jewell et al., 2014 and so on). But the relation between women's labor force participation and child mortality is quite complicated. Not get full attention from its mother and deprived of breastfeeding of children with the participation of mothers in the labor force will adversely affect children's health. However, the family with the participation of mothers in the labor force will increase his revenue which will have a positive impact on child nutrition and health. So the net impact on child mortality of female participation in the labor force depends on the relative strength of these two effects (Tulasidhar, 1993:179).

In the Millennium Development Goals Report Turkey 2010 about Turkey it was stated that the important variations to female's education on getting help from medical staff during

\footnotetext{
${ }^{3}$ It is used the arithmetic mean of infant mortality rate (probability of dying between birth and age 1 per 1000 live births), neonatal mortality rate (per 1000 live births) and under-fivemortality rate data (probability of dying by age 5 per 1000 live births) taken from W HO as dependent variable in our study. Mortality rate (MR hereafter) refers this arithmetic mean.
} 
childbirth, the place of residence, age, the status and number of births were seen. In this context, especially living in the eastern regions of Turkey, it is stated that women with no education or primary school education with the lowest level of prosperity compared to women with high school or higher education with high levels of prosperity is less likely to recieve medical assistance during birth and as the welfare level of household and mother's education level rise, significant increases in the ratios of receiving post-natal care are seen (SPO, 2010:39-43).

Gordon (2009) has made logistic regression analysis by taking maternal education, age, place of residence and the income as the socio-economic determinants of infant and child mortality in Haiti. It has been identified that child mortality decreases while mother's income and level of education increases, however, as age increases, child mortality increases. Dallolio et al. (2012) have considered the relation among the socio-economic factors such as income inequality, the average household income level, women's education levels and unemployment rates with infant mortality in Italy. Within the framework univariate linear regression models that they established, as it was found a strong and positive relationship between women's unemployment rate and income inequality with infant mortality, a significant and negative relationship between average income and educational level of women was found. Pena et al. (2000), in a study conducted for Nicaragua, have expressed that social inequalities such as the absolute poverty level increase the infant mortality risk, therefore, the education of women in poor households can contribute to the prevention of infant death.

It is pointed that the impact of the mother's educational level on child mortality was more important according to other socio-economic factors in some researches on the subject. For example, Caldwell and McDonald (1982), in their study on Nigeria, has stressed that the being educated of the mother reduces child mortality and even parental education level is more important than both the income factor and access to health facilities. Similarly, Tulasidhar (1993), which studies about India, stated that child mortalities were inversely proportional with both maternal educational level and the participation of women in the labor force.

Alemayehu et al. (2015) examined three important issues in their papers on Ethiopia. These are: 1) the relationship between women's education situation and infant death, 2) whether this connection is derived from woman's empowerment and household wealth, and 3) whether the relationship between infant mortality and the education and empowerment of 
women is determined by household wealth in Ethiopia. Their results support the hypothesis that women's education level is conversely affiliated with infant death.

According to Adhikari and Sawangdee (2011), infant mortality is very great in Nepal. In many societies, the fact that women have lower social status and their position in the household adversely affects health of their children and themselves. In Nepal, women's autonomy has a vital role on prediction of infant mortality. According to them, mothers' literacy and decision-making power regarding health care are the most important instruments for reducing infant mortality in Nepal. Hence, in order to reduce infant mortality, female education should be pursued and enlarged to cover every woman.

According to Nyari et al. (2015) investigating the connection between maternal education and infant mortality in Hungary for 1963-2012 era, mothers with the lower education level mothers have highly increased the infant death risk in comparasion with the more educated groups.

Jewell et al. (2014) found that socio-economic status has a negative relationship with infant mortality, implying that the policies improving maternal socio-economic status can emerge important improvements in infant health. They conclude that a maternal educational accession in low level, delivery in a public institution, and maternal unwed status, which is a determinative of low socio-economic status, are positively correlated with infant mortality (Jewell et al. 2014:323).

According to He et al. (2015), mother's age, marital status, maternal race, whether or not is with maternal education, the month that maternal prenatal care began, and weight in birth play highly the vital roles in identfying the ratio of infant death in the US between 2005 and 2009.

Tacke and Waldmann (2013) have found a statistically significant and positive correlation between infant mortality and income inequality by using cross-national data for 93 countries.

In spite of the fact that the rate of working women is considered as an indicator for strenghthening woman's socio-economic position in the millennium development goals, the death rate of the working women's children was found to be higher compared with not working women's in some studies (Basu and Basu, 1991; Sivakami, 1997). Sivakami (1997), which analyzed the relationship between maternal work and child health by surveying a sample composed of working and non working 150 women in a village of India, identified 
that working women in comparasion with non working women allow less time both child care and breastfeeding. Hence, he stated that the children of working women faces more the death risks.

According to Song and Burgard (2011:356) who analyzed the relationship between mother's education state and infant mortality in China for the term 1970-2001, the connection between this variables is largely negative. Consequently they have found that infants of better educated mothers preserved an important advantage in terms of survival along the surveying time.

\section{METHODS AND DATA}

In econometric analyses, three types of data are generally used: time series, crosssectional data and panel data (or longitudinal data) obtained by getting mixed time series and cross-sectional data (Gujarati, 2004:25). The structure of panal data is as in the Table 1.

Table 1: The Structure of Panel Data

\begin{tabular}{|c|c|c|}
\hline Dependent Variable & Explanatory Variable & Random Error \\
\hline $\mathrm{Y}_{1,1}$ & $\mathrm{X}_{1,1}$ & $\mathrm{e}_{1,1}$ \\
\hline $\mathrm{Y}_{1, \mathrm{~T}}$ & - & - \\
\hline $\mathrm{Y}_{2,1}$ & $\mathrm{X}_{1, \mathrm{~T}}$ & $\mathrm{e}_{1, \mathrm{~T}}$ \\
\hline $\mathrm{Y}_{2, \mathrm{~T}}$ & $\mathrm{X}_{2,1}$ & $\mathrm{e}_{2,1}$ \\
\hline $\mathrm{Y}_{\mathrm{N}, 1}$ & - & $\mathrm{e}_{2, \mathrm{~T}}$ \\
\hline $\mathrm{Y}_{\mathrm{N}, \mathrm{T}}$ & $\mathrm{X}_{2, \mathrm{~T}}$ & $\mathrm{eN}_{1}$ \\
\hline & $\mathrm{X}_{\mathrm{N}, 1}$ & - \\
\hline & - & $\mathrm{eN}_{\mathrm{N}, \mathrm{T}}$ \\
\hline
\end{tabular}

*For $\mathrm{i}=1, \ldots ., \mathrm{N}$ Countries and $\mathrm{T}=1, \mathrm{~T}$ years

In our study, panel unit root tests were used to understand whether the series are stationary or nonstationary. One of the most vital using areas of the panel unit root tests in the literature is undoubtedly to test the purchasing power parity (PPP) hypothesis (Pesaran, 2007). Quah (1994) and Levin et al. (2002) have presented very highly important contributions in the advancing of panel unit root tests. The heterogeneity across groups is not provided in the tests suggested by Quah. But it is allowed both dynamic heterogeneity across groups and individual specific effects in LL's test (Im et al. 2003:54).

Panel unit root tests is grouped as first and second generation tests. The cross-sectional independency is one of the basic assumptions of the first generation panel unit root tests. So, according to the first generation tests, the each one of time series in the panel is cross sectionally independent (Maddala and Wu, 1999; Im et al. 2003; Levin et al. 2002). In other words, the constraint of cross-sections independency is the general characteristic of first generation tests. The purpose of second generation panel unit root tests is to supply the reliable outcomes under the cross-sectional dependence. According to Phillips and Sul (2003), 
Moon and Perron (2004), and Bai and Ng (2004), the cross-sectional dependence is driven by elements in the error terms (Hanck, 2013; Hurlin and Mignon, 2007).

In our emprical analysis, we use annual data for the period 2000-2014. First, we investigate whether the null hypothesis related with the presence of a unit root in the (natural logarithms of) labour force participation rate (LFPR) of women in OECD countries is right or not. Then, we search for stationarity in the (natural logarithms of) infant mortality rate (MR).

We investigate the relative importance of gender inequality in explaining the infant mortalities by estimating a panel data of OECD countries for the period 2000-2014.

Infant mortality rates ${ }^{4}$ and labour force participation rate of women being indicator of the gender inequality were respectively extracted from the World Health Organization database and the Organization for Economic Co-operation and Development Database (OECD.Stat) for the period 2000-2014. We used eviews 10 program in our analyses.

\section{EMPRICAL RESULTS}

In order to illustrate the relationship between MR and LFPR, we conduct the stationary and cointegration tests. Section 4.1 searches whether MR and LFPR series have cross sectional-dependence and a unit root. Section 4.2 tests a cointegration relation between MR and LFPR.

\subsection{Cross-Sectional Dependence and Panel Unit Root in MR and LFPR Series}

When we want to perform unit root test on panel data, also the cross-sectional dependence must be tested. If the cross-sectional dependence is rejected in the panel data set, the first generation panel unit root tests can be used. The second generation panel unit root tests can allow more consistent, efficient and robust estimations if the panel data have cross sectional dependence. If $\mathrm{N}$ is bigger than $\mathrm{T}$, the Pesaran CDLM test can be used to test crosssectional dependence in the panel data set (Çınar, 2010; Yıldırım et al. 2013). The results of Cross-Sectional Dependence test for (natural logarithms of) MR and LFPR are provided in Table 2.

\footnotetext{
${ }^{4}$ It is used the arithmetic mean of infant mortality rate (probability of dying bet ween birth and age 1 per 1000 live births), neonatal mortality rate (per 1000 live births) and under-five mortality rate data (probability of dying by age 5 per 1000 live births) taken from WHO as dependent variable in our study. Mortality rate (MR hereafter) refers this arithmetic mean.
} 
Table 2: Cross-Section Dependence Test (Period/Cross-section:15/33)

\begin{tabular}{|l|l|l|l|l|l|l|}
\hline \multirow{2}{*}{ Test } & \multicolumn{2}{c|}{ Statistic } & \multicolumn{2}{c|}{ Probability } & \multicolumn{2}{c|}{ d.f. } \\
\cline { 2 - 6 } & LFPR & MR & LFPR & MR & LFPR & MR \\
\hline Breusch-Pagan LM & 3476.555 & 7279.336 & 0.0000 & 0.0000 & 528 & 528 \\
\hline Pesaran scaled LM & 89.71999 & 206.7425 & 0.0000 & 0.0000 & & \\
\hline Bias-corrected scaled LM & 88.54142 & 205.5639 & 0.0000 & 0.0000 & & \\
\hline Pesaran CD & 23.47450 & 85.19848 & 0.0000 & 0.0000 & & \\
\hline
\end{tabular}

As seen from Table 2, according to Pesaran CD test both LFPR and MR series have cross-section dependence. No cross-section dependence (corelation) null hypothesis can be rejected at the conventional levels of significance. So the low p-values suggest that the null hypothesis can be rejected. For this reason, whether the series are stationary should be assessed using the second generation panel unit root tests.

In our study, whether the series are stationary or not is tested by using the Pesaran Cross-Sectionally Augmented Dickey Fuller Test (CADF, hereafter) test from second generation unit root tests. We apply the Pesaran CADF test to investigate the unit root properties for MR and LFPR variable in each of the 33 countries in our sample. We select 0 and 1 lags as the lag length. While one of the predicted models is without a time trend, the other is with a time trend. Pesaran CADF uses the t-test for unit roots in heterogenous panels with cross-section dependence. The results based on the Pesaran CADF test are indicated in Table 3.

Table 3: Pesaran Panel Unit Root Test

\begin{tabular}{|l|l|l|l|l|l|l|l|l|}
\hline \multirow{3}{*}{$\begin{array}{c}\text { Variables/ } \\
\text { CADF Test }\end{array}$} & \multicolumn{4}{|c|}{ Level } & \multicolumn{4}{c|}{ First Diffirence } \\
\cline { 2 - 9 } & \multicolumn{1}{|c|}{ Without Trend } & \multicolumn{2}{|c|}{ With Trend } & Without Trend & With Trend \\
\hline MR(-bar] & P-value & Z[t-bar] & P-value & Z[t-bar] & P-value & Z[t-bar] & P-value \\
\hline LFPR(0) & -0.16 & -0.436 & -0.582 & 0.280 & -8.029 & 0.000 & -5.191 & 0.000 \\
\hline MR(1) & -1.092 & 0.137 & -0.357 & 0.360 & -9.237 & 0.000 & -7.579 & 0.000 \\
\hline LFPR(1) & -0.410 & 0.341 & -0.742 & 0.229 & -4.851 & 0.000 & -2.937 & 0.002 \\
\hline
\end{tabular}

*The Pesaran CADF test was done by using stata 14. 2 program.

The results in Table 3 show that $Z(t-b a r)$ test statistic failed to reject the null hypothesis of the presence of unit root for both variables in the panel in levels. The high pvalues suggest that the unit root null hypothesis for LFPR and MR cannot be rejected. Hence, the CADF test confirmed that LFPR and MR were non-stationary in level. We concluded that the unit root null hypothesis is been able to rejected at the conventional levels of significance for both variables' first difference while it is been unable to rejected at the 5 per cent level of significance for the (natural logarithmic) levels of variables. MR and LFPR are clearly stationary in first differences and non-stationary in levels according to Pesaran CADF test. From these findings, we have arrived the result that the variables are integrated of order one. The next phase is to test whether the series are co-integrated. 


\subsection{The Cointegration Relation Between MR and LFPR Variables}

In order to establish a long-term relationship between the variables, firstly it should be determined whether there is a cointegration relation between the variables integrated at the same level. For this purpose, in our study whether there is a cointegration relation between MR and LFPR was investigated. We use the Panel Pedroni Residual Cointegration Test, based on Engle-Granger two-step cointegration tests, recommended by Pedroni $(1999,2004)$ to test the relation of panel cointegration between MR and LFPR. The results are reported in Table 4. The panel cointegration test has been used under the condition that the variables are integrated from the same degree. So we use a model with intercept and trend to test cointegration relation.

Table 4: Pedroni Residual Cointegration Test

\begin{tabular}{|c|c|c|c|c|}
\hline \multicolumn{5}{|c|}{ Pedroni Residual Cointegration Test } \\
\hline \multicolumn{5}{|c|}{ Series: MR LFPR } \\
\hline \multicolumn{5}{|c|}{ Date: $07 / 26 / 17$ Time: $14: 16$} \\
\hline \multicolumn{5}{|c|}{ Sample: 20002014} \\
\hline \multicolumn{5}{|c|}{ Included observations: 495} \\
\hline \multicolumn{5}{|c|}{ Cross-sections included: 33} \\
\hline \multicolumn{5}{|c|}{ Null Hypothesis: No cointegration } \\
\hline \multicolumn{5}{|c|}{ Trend assumption: Deterministic intercept and trend } \\
\hline \multicolumn{5}{|c|}{ Automatic lag length selection based on SIC with a max lag of 2} \\
\hline \multicolumn{5}{|c|}{ Newey-West fixed bandwidth and Bartlett kernel } \\
\hline \multicolumn{5}{|c|}{ Alternative hypothesis: common AR coefs. (within-dimension) } \\
\hline & Statistic & Prob. & $\begin{array}{c}\text { Weighted } \\
\text { Statistic } \\
\end{array}$ & Prob. \\
\hline Panel v-Statistic & 90.46521 & 0.0000 & 41.83866 & 0.0000 \\
\hline Panel rho-Statistic & 1.393391 & 0.9182 & 1.101544 & 0.8647 \\
\hline Panel PP-Statistic & -1.299447 & 0.0969 & -1.826358 & 0.0339 \\
\hline Panel ADF-Statistic & -1.919441 & 0.0275 & -2.053068 & 0.0200 \\
\hline \multicolumn{5}{|c|}{ Alternative hypothesis: individual AR coefs. (between-dimension) } \\
\hline & \multicolumn{2}{|c|}{ Statistic } & \multicolumn{2}{|c|}{ Prob. } \\
\hline Group rho-Statistic & \multicolumn{2}{|c|}{2.553587} & \multicolumn{2}{|c|}{0.9947} \\
\hline Group PP-Statistic & \multicolumn{2}{|c|}{-2.348875} & \multicolumn{2}{|c|}{0.0094} \\
\hline Group ADF-Statistic & \multicolumn{2}{|c|}{-3.307631} & \multicolumn{2}{|c|}{0.0005} \\
\hline
\end{tabular}

As we can see from the Table 4, we can refuse the null hypothesis that there is no cointegration according to a majority of the test statistics at the conventional levels of significance due to low $\mathrm{p}$ rates without Panel rho-Statistics and Group rho Statistics. We conclude that there is a cointegration relation between MR and LFPR variables.

Upon finding a cointegration relationship between MR and LFPR for the panel of 33 OECD countries, we guess the long-run elasticities related the effect of LFPR on MR in this section. To achieve this, as explained earlier, we use the Panel Dynamic Least Squares (hereafter DOLS) and Panel Fully Modified Least Squares (herafter FMOLS) estimators. We estimate the model including a trend and intercept. The results are reported in Table 5 and 6 . We sum up our results as follows. First, we have found that LFPR has a statistically 
significant and negative effect on MR for the panel of 33 OECD countries. In addition, we can say that the relation between LFPR and MR is also consistent with theory.

Table 5: Panel Dynamic Least Squares Coefficient Estimations

\begin{tabular}{|c|c|c|c|c|}
\hline \multicolumn{5}{|c|}{ Dependent Variable: MR } \\
\hline \multicolumn{5}{|c|}{ Method: Panel Dynamic Least Squares (DOLS) } \\
\hline \multicolumn{5}{|c|}{ Sample (adjusted): 20022013} \\
\hline \multicolumn{5}{|c|}{ Periods included: 12} \\
\hline \multicolumn{5}{|c|}{ Cross-sections included: 33} \\
\hline \multicolumn{5}{|c|}{ Total panel (balanced) observations: 396} \\
\hline \multicolumn{5}{|c|}{ Panel method: Pooled estimation } \\
\hline \multicolumn{5}{|c|}{ Cointegrating equation deterministics: $\mathrm{C}$} \\
\hline \multicolumn{5}{|c|}{ Fixed leads and lags specification (lead=1, lag=1) } \\
\hline \multicolumn{5}{|c|}{ Coefficient covariance computed using default method } \\
\hline \multicolumn{5}{|c|}{$\begin{array}{l}\text { Long-run variance (Bartlett kernel, Newey-West fixed bandwidth) used for } \\
\text { coefficient covariances }\end{array}$} \\
\hline Variable & Coefficient & Std. Error & t-Statistic & Prob. \\
\hline LFPR & -2.141948 & 0.285006 & -7.515438 & 0.0000 \\
\hline R-squared & 0.958668 & Mean depender & & 1.441977 \\
\hline Adjusted R-squared & 0.937923 & S.D. dependent & & 0.474341 \\
\hline S.E. of regression & 0.118183 & Sim sounad & & \\
\hline Long-run variance & 0.017948 & Sum squared $\mathrm{r}$ & & $3.0 / 33 / 2$ \\
\hline
\end{tabular}

According to Panel DOLS results, there is a negative relation between MR and LFPR. The coefficient of LFPR is a statistically significant and is also suitable for theoretical expectations. We find that LFPR has a negative impact on MR. A 1 per cent increase in LFPR give rise to a 2.14 per cent decrease in MR.

Table 6: Panel Fully-Modified Least Squares Coefficient Estimations

\begin{tabular}{|c|c|c|c|}
\hline \multicolumn{4}{|c|}{ Dependent Variable: MR } \\
\hline \multicolumn{4}{|c|}{ Method: Panel Fully Modified Least Squares (FMOLS) } \\
\hline \multicolumn{4}{|c|}{ Sample (adjusted): 20012014} \\
\hline \multicolumn{4}{|c|}{ Periods included: 14} \\
\hline \multicolumn{4}{|c|}{ Cross-sections included: 33} \\
\hline \multicolumn{4}{|c|}{ Total panel (balanced) observations: 462} \\
\hline \multicolumn{4}{|c|}{ Panel method: Pooled estimation } \\
\hline \multicolumn{4}{|c|}{ Cointegrating equation deterministics: $\mathrm{C}$} \\
\hline \multicolumn{4}{|c|}{ Coefficient covariance computed using default method } \\
\hline \multicolumn{4}{|c|}{ Long-run covariance estimates (Bartlett kernel, Newey-West fixed bandwidth) } \\
\hline Variable & Coefficient & Std. Error & Prob. \\
\hline LFPR & -2.136192 & -8.467845 & 0.0000 \\
\hline R-squared & 0.913646 & Mean dependent var & 1.443900 \\
\hline Adjusted R-squared & 0.906987 & S.D. dependent var & 0.480985 \\
\hline S.E. of regression & 0.146691 & Sum squared resid & 9.209762 \\
\hline Long-run variance & 0.048687 & & \\
\hline
\end{tabular}

According to panel FMOLS results, a 1 per cent increase in women's LFPR give rise to a 2.14 per cent decrease in MR. LFPR has a negative and significant effect on MR. 


\section{CONCLUSION}

It can be expressed that maternal health, socio-economic conditions, and public health practices are very highly important factors in the explaining away of infant mortalities. Reduction of child mortality, which is a major developmental goal itself too, should constitute an important support for a country trying to eradicate poverty and social inequalities. Public programs aimed at reducing infant mortalities may be an important instrument in improving economic development.

In the final analysis, the conclusions of the present study supported our hypothesis. Mortality rates may decline as a result of the increase (in other words, the decrease in gender inequality) in labour force participation rates of women.

We analysed in our study how women's socio-economic situations affect infant mortalities in OECD countries for the period 2000-2014. It can be said that the labor force participation rate of women, an important element of gender inequality, has a statistically powerful effect on infant mortality. The labor force participation rate of women and gender inequality have a negative relationship. As women's labour force participation rate increases, gender inequality decreases. So, as gender inequality decreases, infant mortality rates also decrease.

According to our findings, it can be said that the reducing of gender inequality is an important element in decreasing infant/child/under five mortality rates. This conclusion further increases the important of "the target of ensuring gender equality" accepted as one of the indicators of social development. 


\section{REFERENCES}

Adhikari, R., and Sawangdee, Y. (2011). Influence of women's autonomy on infant mortality in Nepal. Reproductive Health Journal, 8 (7), 1-8.

Alemayehu, Y.K., Theall, K., Lemma, W., Hajito, K.W., Tushune, K. (2015). The role of empowerment in the as sociation between a woman's educational status and infant mortality in Ethiopia: Secondary analysis of demographic and health surveys. Ethiopian Journal ofHealth Sciences, 25 (4), 353-362.

Bai, J., and Ng, S. (2004). A panic attack on unit roots and cointegration. Econometrica, 72 (4), 1127-1177.

Basu, A.M., and Basu, K. (1991). Women's economic roles and child survival: the case of India. Health Transition Review, 1 (1), 83-103.

Caldwell, J., and McDonald, P. (1982). Influence of maternal education on infant and child mortality: Levels and causes. Health Policy and Education, 2 (3-4), 251-267.

Cleland, J.G., and Van Ginneken, J.K. (1988). Maternal education and child survival in developing countries: The search for pathways of influence. Social Science \& Medicine, 27 (12), 1357-1368.

Çınar, S. (2010). OECD ülkelerinde kişi başına GSYİH durağan mı? Panel veri analizi. Marmara Üniversitesi IIIBF Dergisi, 19 (2), 591-601.

Dallolio, L., Di Gregori, V., Lenzi, J., Franchino, G., Calugi, S., Domenighetti, G., and Fantini, M.P. (2012). Socio-economic factors associated with infant mortality in Italy: An ecological study. International Journal for Equity in Health, 11 (45), 1-5.

Gordon, R.M. (2009). Socio-economic determinants of infant and child mortality in Haiti. Journal of Eastern Caribbean Studies, 34 (1), 1-19.

Gujarati, D.N. (2004). Basic econometrics. $4^{\text {th }}$ ed. New York: The McGraw-Hill.

Hanck, C. (2013). An intersection test for panel unit roots. Econometric Reviews, 32 (2), 183-203.

He, X., Akil, L., Aker, W.G., Hwang, H-M., and Ahmad, H.A. (2015). Trends in infant mortality in United States: A brief study of the Southeastern States from 2005-2009. International Journal of Environmental Research and Public Health, 12 (5), 4908-4920.

Im, K.S., Pesaran, M.H., and Shin, Y. (2003). Testing for unit roots in heterogeneous panels. Journal of Econometrics, 115 (1), 53-74.

Houweling, T.A.J., and Kunst, A.E. (2010). Socio-economic inequalities in childhood mortality in low- and middle-income countries: a review of the international evidence. British Medical Bulletin, 93 (1), 7-26. 
Hurlin, C., and Mignon, V. (2007). Second generation panel unit root tests. Available from: https://halshs.archives -ouvertes.fr/halshs-00159842.

Jewell, R.T., Martinez, J., and Triunfo, P. (2014). Infant mortality in Uruguay: The effect of socio-economic status on survival. The Journal of Developing Areas, 48 (2), 307-328.

Levin, A., Lin, C.F., and Chu, C.S.J. (2002). Unit root tests in panel data: Asymptotic and finite-sample properties. Journal of Econometrics, 108 (1), 1-24.

Maddala, G.S., and Wu, S. (1999). A comparative study of unit root tests with panel data and a new simple test. Oxford Bulletin of Economics and Statistics, 61(S1), 631-652.

Mustafa, H.E., and Odimegwu, C. (2008). Socio-economic determinants of infant mortality in Kenya: Analysis of Kenya DHS 2003. Journal of Humanities and Social Sciences, 2 (2), 1-16.

Moon, H.R.,and Perron, B. (2004). Testing for a unit root in panels with dynamic factors. Journal of Econometrics, 122 (1), 81-126.

Nyari, C., Nyari, T.A., and McNally, R.J.Q. (2015). Trends in infant mortality rates in Hungary between 1963 and 2012. Acta Paediatrica, 104 (5), 473-478.

OECD (2017). Available from: http://stats.oecd.org/index.aspx? DatasetCode= GENDER_ EMP (Data extracted on 28 Nov 2016 14:36 UTC (GMT) from OECD.Stat)

Pena, R., Wall, S., and Persson, L.A. (2000). The effect of poverty, social inequity, and maternal education on infant mortality in Nicaragua, 1988-1993. American Journal of Public Health, 90 (1), 64-69.

Pedroni, P. (1999). Critical values for cointegration tests in heterogeneous panels with multiple regressors. Oxford Bulletin of Economics and Statistics, 61(S1), 653-670.

Pedroni, P. (2004). Panel cointegration: Asymptotic and finite sample properties of pooled time series tests with an application to the PPP hypothesis. Econometric Theory, 20(3), 597-625.

Pesaran, M.H. (2007). A simple panel unit root test in the presence of cross section dependence. Journal of Applied Econometrics, 22 (2), 265-312.

Phillips, P.C.B., and Sul, D. (2003). Dynamic panel estimation and homogeneity testing under cross section dependence. The Econometrics Journal, 6 (1), 217-259.

Quah, D. (1994). Exploiting cross-section variations for unit root inference in dynamic data. Economics Letters, 44 (1-2), 9-19.

Sivakami, M. (1997). Female work participation and child health: an investigation in rural Tamil Nadu, India. Health Transition Review, 7 (1), 21-32. 
Song, S., and Burgard, S.A. (2011). Dynamics of inequality: Mother's education and infant mortality in China, 1970-2001. Journal of Health and Social Behavior, 52 (3), 349-364.

SPO (The State Planning Organization of Turkish Republic) (2010). Binyıl kalkınma hedefleri raporu Türkiye 2010, Ankara.

Şimşek, M. (2014). Being a woman in OECD countries: An application. Journal of Academic Research in Economics, 6 (2), 179-193.

Tacke, T., and Waldmann, R.J. (2013). Infant mortality, relative income and public policy. Applied Economics, 45 (22), 3240-3254.

Tulasidhar, V.B. (1993). Maternal education, female labour force participation and child mortality: evidence from the Indian census. Health Transition Review, 3 (2), 177-190.

UNDP (2014). The millennium development goals report 2014. Available from: http://www.tr.undp.org/content/dam/turkey/docs/Publications/mdgs/MDG\%202014\%20English\%20we b.pdf, Access Date:14.10.2014.

Yildırım, K., Mercan, M., and Kostakoğlu, S.F. (2013). Test for validity of purchasing power parity: Time series and panel data analysis. Eskişehir Osmangazi Üniversitesi IIBBF Dergisi, 8 (3), 75- 95.

WHO (2017). Available from: http://apps.who.int/gho/data/node.home Date generated: 2017-03-31 14:52:30.0 Source URL: http://apps.who.int/gho/athena/data/GHO/ MDG 0000000007,MDG_0000000001,WHOSIS_000003?filter=COUNTRY:*;REGION:* \&format=x ml\&profile $=$ exce 1 
Appendix 1: Counrty List

\begin{tabular}{|c|}
\hline Countries \\
\hline Australia \\
\hline Austria \\
\hline Belgium \\
\hline Canada \\
\hline Chile \\
\hline Czech Republic \\
\hline Denmark \\
\hline Estonia \\
\hline Finland \\
\hline France \\
\hline Germany \\
\hline Greece \\
\hline Hungary \\
\hline Iceland \\
\hline Ireland \\
\hline Israel \\
\hline Italy \\
\hline Japan \\
\hline Luxembourg \\
\hline Mexico \\
\hline Netherlands \\
\hline New Zealand \\
\hline Norway \\
\hline Poland \\
\hline Portugal \\
\hline Slovak Republic \\
\hline Slovenia \\
\hline
\end{tabular}




\begin{tabular}{|l|}
\hline Spain \\
\hline Sweden \\
\hline Switzerland \\
\hline Turkey \\
\hline United Kingdom \\
\hline United States \\
\hline
\end{tabular}

